
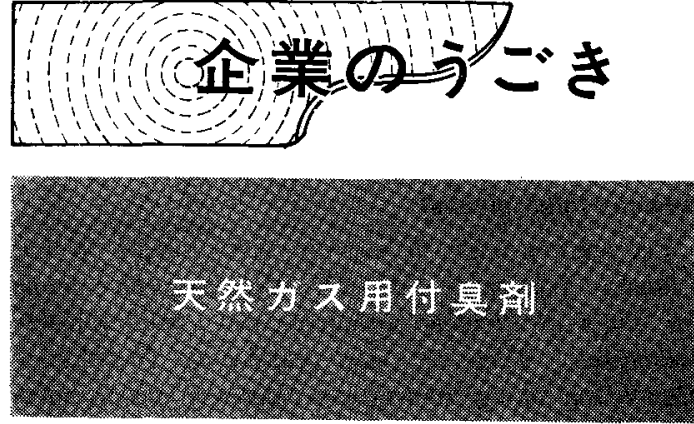

\section{Pf a}

1 はじめに

ガスの漏洩による災害を防止するために，都市ガスに はある種の付臭剤を添加し，少量のガス漏洩も感知でき るようにしている・

当社の供給ガスは $0^{\circ} \mathrm{C} 1$ 気在の標準状熊では 5,000 $\mathrm{kcal} / \mathrm{m}^{3}$ の製造ガス（6 Bガス）上天然ガスを主成分と する $11,000 \mathrm{kcal} / \mathrm{m}^{3}$ のガス (13 A ガス)の2種類あ るが，後者に適した混合付臭剤を新たに開発し，現在実 用している。以下に開発の経緯と新付臭悡の概要につい 一紹介する。

\section{2 付臭剂について}

都市ガス用付臭剂は，一般的に次の条件を具備してい ろことが望屯しい.

(a) 無毒である.

(b) ごく少量で付臭効果が出る.

(c) 然焼後は無臭になる.

（d）供給系統八の腐食障害, 導管内での凝縮, 化学 这店起さない。

(e) 家庭の臭い，その他に臭質が類似しない。

（f）水に難容性である.

（g）価格が低廉である.

（） 硫黄分や窒素分を多量に含有しない.
一般的に言って，慕いの根源は化合物中の硫黄・窒素 などの特定元素か，またはハロゲン族に由来する場合が 多く, それ以外は化学的に不安定な二重結合, 三重結合 ないしはカルボキシル基，アルデヒド基などの活性な官 能基に由来していると言われている。

\section{3 新付臭郕開発の必要性}

上記の条件を満足させるため, 現在 $6 \mathrm{~B}$ ガスにはテ トラヒドロ・チオフェン(THT) をベースにした二成分 系付臭剤が添加されている。参考までに THT の物性を 表 1 に示す.

表 1 テトラヒドロ・チオフェンの物性

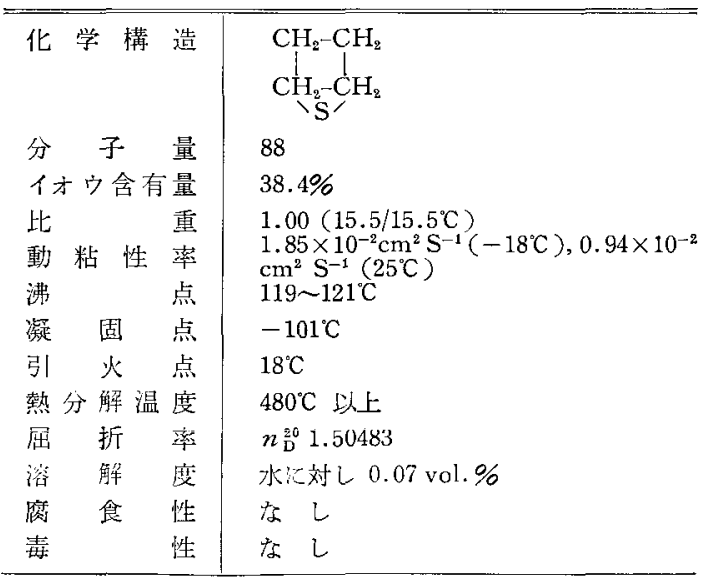

一方, 最近都市ガスに広く利用されている天然ガスに は，徉来の THT をベースにした混合付臭用は臭質的に 最適な付臭剂上は言いがたいため，天然ガスのクリーン なイメージに合うよう可能な限り硫黄分を減少させ，し かも臭の強さを落さない $13 \mathrm{~A}$ ガスに適した付臭剤の開 発が必要になった。

\section{4 新付臭剤の選定試験}

まず硫黄を含まない物質数十種とTHTよりも強臭を

表 2 付具剤の対象となる有機化合物

\begin{tabular}{|c|c|c|c|c|c|c|}
\hline 名 & 分子 式 & 硫黄分(\%) & $\mid$ 沸点 $\left.{ }^{\circ} \mathrm{C}\right) \mid$ & 液比重 & $\begin{array}{l}\text { 閥 值 } \\
(\mathrm{ppb})\end{array}$ & 備 \\
\hline テトラヒドロチオフェン & $\mathrm{C}_{4} \mathrm{H}_{8} \mathrm{~S}$ & 36.4 & 119 & 0.998 & 0.77 & ガス息 \\
\hline ジメチルサルフフイド & $\mathrm{CH}_{8} \mathrm{SCH}_{3}$ & 51.7 & 36 & 0.847 & 2.5 & にえにくの腐敗貞 \\
\hline t-ブチルメルカプタン & $\left(\mathrm{CH}_{3}\right)_{3} \mathrm{CSH}$ & 35.6 & 64 & 0.800 & 0.09 & 玉桂の窝敗臭 \\
\hline モノメチルアミン & $\mathrm{CH}_{3} \mathrm{NH}_{2}$ & & 6 & 0.699 & 0.21 & 魚の腐敗臭 \\
\hline トリメチルアミン & $\left(\mathrm{CH}_{3}\right)_{3} \mathrm{~N}$ & & 3 & 0.662 & 0.21 & $n$ \\
\hline トリエチルフミン & $\left(\mathrm{C}_{2} \mathrm{H}_{5}\right)_{3} \mathrm{~N}$ & & 89 & 0.726 & & $"$ \\
\hline アクリル酸エチル & $\mathrm{CH}_{2} \mathrm{CHCOOC}_{2} \mathrm{H}_{3}$ & & 100 & 0.924 & 0.47 & プラスチックの焼真 \\
\hline アリルエーテル & $\left(\mathrm{CH}_{2} \mathrm{CHCH}_{2}\right)_{2} \mathrm{O}$ & & 94 & 0.826 & & $n$ \\
\hline$n$-酪酸 & $\mathrm{CH}_{3}\left(\mathrm{CH}_{2}\right)_{2} \mathrm{COOH}$ & & 162 & 0.959 & 1.0 & ミルクの腐敗臭 \\
\hline n-吉草酸 & $\mathrm{CH}_{5}\left(\mathrm{CH}_{2}\right)_{8} \mathrm{COOH}$ & & 186 & 0.939 & 0.6 & 足裹の不潔臭 \\
\hline イソブチルアルデヒド & $\left(\mathrm{CH}_{3}\right)_{2} \mathrm{CHCHO}$ & & 65 & 0.794 & & 揮発性溶剽臭 \\
\hline
\end{tabular}


有する有機化合物を選択して，これらをエチレングリコ ールまたは表面活性剤を加えた水に溶解し，漸次希釈し て閾濃度となる希採倍率から臭強度を判定し，選別を行 なった、このスクリーニングで残った強臭物質を表 2 に 示す.これらの物質に対して次のような各種項目の試験 を実施し，侯補物質をさらにしぼっていった。

1) 臭度試験

付臭ガスを空気中で 100 倍に希釈した場合の臭強度を 測定寸る。

\section{2) 腐食試験}

鋳鉄, 高張力鋼, 銅, その他の金属材料を十分に研磨 した試験片を図 1 のように付臭㶡，水の 2 液相に半分浸 せきさせ，上半分在飽和蒸気にさらす．そして表面観察 やX線回折などによって腐食の度合老調べる。

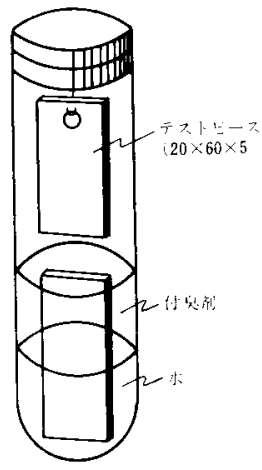

図 1 金属材料に対する腐食試験

\section{3）鉄錆吸着試験}

鉄錆による吸着は，付臭剤を十分に飽和吸着した導管 では問題ないが新設導管においては大きな問題となる。

本試験では，一定量の付臭ガスを系内に封じ込め付臭 剤濃度を経時的に測定し，その濃度変化率加ら鉄錆八の 吸着性を判定する。

4) 水溶性試験

一定濃度に付臭したガスを臭度测定室へ直接送入した 場合と，直前に水塔を通して臭度測定室に送入した場合 の臭度比較により行なら。

5）土壤吸着性試験

一定濃度に付臭したガスを臭度測定窒へ直接送入した 場合上，直前に関東ロームを軽装填した土層を通した後 に臭度測定室へ送入した場合の臭度比較により判定す る.

\section{5 単味付臭剤と混合付奥剂}

各種付臭剂候補の適性試験結果を THT と相対的に比 較し，表 3 に示す，その結果，臭度の点で THT に代替 し得ると予想した硫黄分を含まない有機化合物の大部分 が，他の諸物性から単味では付臬剤として使用しにくい
表 3 付臭剂としての適性試験結果 (THT 対比)

\begin{tabular}{|c|c|c|c|c|c|c|}
\hline 物犋名 愐目 & 臭強度 & 真質 & $\begin{array}{l}\text { 金属 } \\
\text { 食 }\end{array}$ & 水棌 & & 鉄錆 \\
\hline t-ブチルメルカプタン & (O) & 0 & $\triangle$ & 0 & 0 & $x$ \\
\hline ジメチルサルフフイド & 0 & 0 & $\Delta$ & 0 & 0 & 0 \\
\hline モノメチルフミン & 0 & 0 & (0) & $x$ & $\Delta$ & $x$ \\
\hline トリメチルフミン & () & 0 & (2) & $x$ & $x$ & $x$ \\
\hline トリエチルすミン & $\triangle$ & $\triangle$ & (a) & $\Delta$ & $\triangle$ & $x$ \\
\hline$n$-酪 酸 & (O) & 0 & $x$ & $x$ & 0 & $\Delta$ \\
\hline$n$-吉 草 酸 & (9) & 0 & $x$ & $\Delta$ & 0 & $\triangle$ \\
\hline アクリル酸エチル & (a) & $x$ & (O) & 0 & 0 & 今 \\
\hline イソブチルフルデヒド & 0 & $x$ & $\Delta$ & $x$ & 0 & $\Delta$ \\
\hline フリルエーテル & 0 & $x$ & $\triangle$ & 0 & 0 & $\triangle$ \\
\hline
\end{tabular}

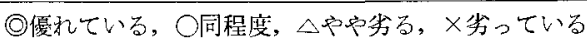

ことがわかった：したがってこれらの有機化合物では 2 種以上を混合することにより互いの久点を補完し，より 優れた付臭剂に調製することが必要になる。

そこでいるいろな組合せを試みたが，非硫黄系どうし の混合ではいずれの場合も満足すべきものが得られなか ったため，硫黄系付臭剤を加えることとした．その結果 アタリル酸エチル (EA) 定ベースとしターシャリーブ チル・メルカプタン(TBM)を $30 \mathrm{wt} \%$ 混合した付臭 郕が十分な臭度を示すことが確認された。そして製法特 許を取得した。な杇 EA と TBM の物性は表 4 のよう である。

表 4 EA と TBM の物性

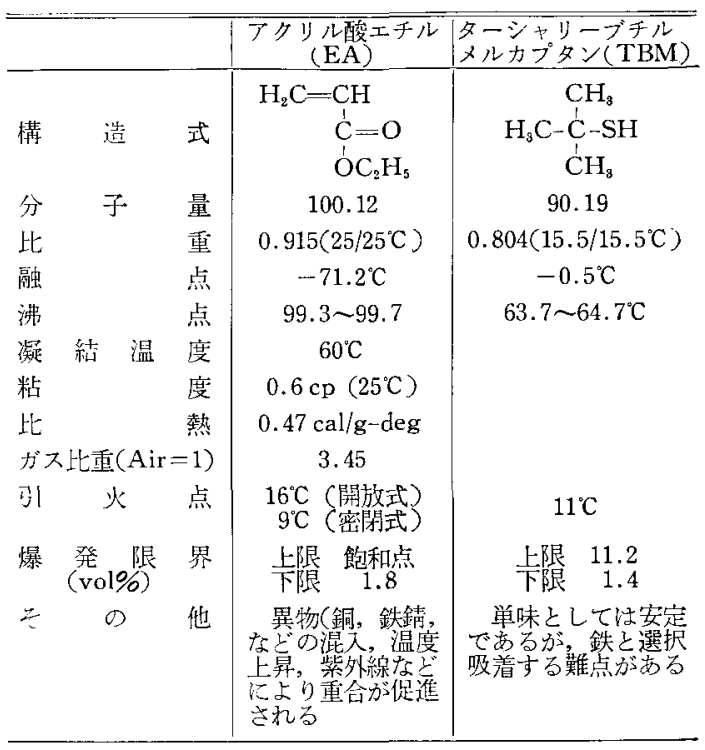

\section{6 新付臭剤の実用化}

新付臭㓮の実用化に先立って，各種の試験を行ないそ の性状を確認した。

金属に対寸る腐食性，ガスメータ一構成部材，導管パ ッキング材，然焼機器のノズルなどに対する影響を調べ 
たが，いずれも問題なかった。

このような基礎試験で十分に使用できる目途がついた ので, 需要家に注直接接続されていない大容量, 高圧ガ ス輸送パイプラインおよび低圧輸送ネットワークでそれ ぞれ実地テストを行ない，付臭片の導管内における挙動 および效果を確認した．そして実ラインでも期待通りの
結果が得られたため，当社送出の $13 \mathrm{~A}$ ガスに添加し， 現在に至っている.

（連絡先：同社技術研究所

研究計画空 河田達也

Tel. 03-452-2211) 